Special JAFSCD Issue Indigenous Food Sovereignty in North America

\section{Building an Indigenous foods knowledges network through relational accountability} \section{sponsored by \\ 1. Swette Center for} Sustainable Food Systems Arizona State University

\author{
Mary Beth Jäger (Citizen Potawatomi Nation) ${ }^{a}$ \\ University of Arizona \\ Daniel B. Ferguson ${ }^{b}$ \\ University of Arizona \\ Orville Huntington (Huslia) ${ }^{c}$ \\ Tanana Chiefs Conference \\ Michael Kotutwa Johnson (Hopi)d \\ University of Arizona \\ Noor Johnson e* \\ University of Colorado \\ Amy Juan (Tohono O'odham Nation) ${ }^{\mathrm{f}}$ \\ Sovereign Remedies LLC \\ Shawna Larson (Ahtna and Supiaq) $g$ \\ Chickaloon Village Traditional Council \\ Peter Pulsifer ${ }^{\text {h }}$ \\ University of Colorado
}

\author{
Tristan Reader ${ }^{\mathrm{i}}$ \\ University of Arizona \\ Colleen Strawhacker ${ }^{i}$ \\ University of Colorado \\ Althea Walker (Akimel O'otham) ${ }^{\mathrm{k}}$ \\ Southwest Climate Adaptation Science Center \\ Denali Whiting (Iñupiaq) ${ }^{1}$ \\ Alaska Humanities Forum \\ Jamie Wilson (Diné) ${ }^{\mathrm{m}}$ \\ University of Arizona \\ Janene Yazzie (Diné) ${ }^{\mathrm{n}}$ \\ Sixth World Solutions \\ Stephanie Russo Carroll (Ahtna) ${ }^{\circ}$ \\ University of Arizona \\ and the rest of the Indigenous Foods \\ Knowledges Network ${ }^{\mathrm{e}}$ \\ University of Colorado \& University of Arizona
}

Submitted January 22, 2019 / Revised March 25, 2019 / Accepted June 4, 2019 / Published online December 9, 2019

Citation: Jäger, M. B., Ferguson, D. B., Huntington, O., Johnson, M. K., Johnson, N., Juan, A., Larson, S., Pulsifer, P., Reader, T., Strawhacker, C., Walker, A., Whiting, D., Wilson, J., Yazzie, J., Carroll, S. R., \& Rest of the Indigenous Foods Knowledges Network. (2019). Building an Indigenous foods knowledges network through relational accountability. Journal of Agriculture, Food Systems, and Community Development, 9(Suppl. 2), 45-51. https://doi.org/10.5304/jafscd.2019.09B.005

Copyright (C) 2019 by the Authors. Published by the Lyson Center for Civic Agriculture and Food Systems. Open access under CC-BY license.

\begin{abstract}
In recent decades, there has been a movement toward rectifying injustices and developing collaborations between Indigenous communities and mainstream researchers to address environmental challenges that are of concern to Indigenous Peo-
\end{abstract}

ples. This movement, primarily driven by Indigenous community leaders and scholars, emphasizes community-driven research that addresses Indigenous People's interests, foregrounds Indigenous Knowledge systems, and both respects and asserts Indigenous sovereignty. This article describes a 
nascent model in the movement- the Indigenous Foods Knowledges Network (IFKN) — designed to connect Indigenous communities and scholars across the Arctic and the U.S. Southwest. IFKN's goal is to foster a network of Indigenous leaders, citizens, and scholars who are focused on research and community capacity related to food sovereignty and resilience. IFKN members collectively work to promote and carry out research that (1) utilizes Indigenous research processes, (2) embraces and respects Indigenous Knowledge systems, and (3) supports Indigenous communities (IFKN, 2018). The authors discuss relational accountability and centering of story, which form the foundation for the methodological approaches and work of IFKN.

\section{Keywords}

Indigenous Food Sovereignty, Governance, Arctic, Indigenous Knowledge, Networks, U.S. Southwest

a Native Nations Institute at the Udall Center for Public Policy, University of Arizona; 803 E. First Street; Tucson, Arizona 85719 USA; jager@email.arizona.edu

${ }^{\mathrm{b}}$ Institute of the Environment, University of Arizona; 1064 E. Lowell Street; P.O. Box 210137 4; Tucson, Arizona 85721 USA; dferg@email.arizona.edu

'Tanana Chiefs Conference; 122 1st Street; Fairbanks, Alaska 99701 USA; orville.huntington@,tananachiefs.org

d School of Natural Resources and the Environment, University of Arizona; Environment and Resources 2; 1064 E. Lowell Street; Tucson, Arizona 85721 USA; kotutwa@email.arizona.edu

e* Corresponding author: Noor Johnson, National Snow and Ice Data Center, CIRES; 449 UCB, University of Colorado; Boulder, Colorado 80309 USA; +1-857-204-5764; noor.johnson@,colorado.edu

${ }^{\mathrm{f}}$ Sovereign Remedies LLC; P.O. Box 97; Sells, Arizona 85643 USA; protecthimdag@gmail.com

g Chickaloon Village Traditional Council; P.O. Box 1105; Chicaloon, Alaska 99874 USA; shawna@carmentree.org

$\mathrm{h}$ National Snow and Ice Data Center, CIRES.

Peter Pulsifer is now at Carleton University; ppulsifer@gcrc.carleton.ca

${ }^{\mathrm{i}}$ American Indian Studies and McGuire Center for Entrepreneurship, University of Arizona; Harvill 226D; P.O. Box 210076; Tucson, Arizona 85721 USA; treader@email.arizona.edu

\section{Introduction}

Indigenous Peoples' homelands in the Arctic and U.S. Southwest are undergoing unprecedented environmental change posing risks to their food systems. These changes follow and accompany massive social and cultural disruptions that occurred and continue to occur as a result of settler colonialism. Efforts to extinguish Indigenous cultures over the last four centuries have largely failed due to the resilience of the peoples and their lifeways. Indigenous communities worldwide are working to revitalize their food systems and assert their food sovereignty. However, the role of mainstream science in the erosion of Indigenous rights and the tendency for non-Indigenous researchers to diminish Indigenous ways of knowing complicate efforts to bring Indigenous and non-Indigenous Knowledge systems into dialogue to address these risks. In recent decades, there has been a small but growing movement to rectify some of these injustices and develop respectful collaborations between Indigenous communities and

j National Snow and Ice Data Center, CIRES; 449 UCB, University of Colorado; Boulder, Colorado 80309 USA; colleen.strawhacker@,colorado.edu

${ }^{\mathrm{k}}$ Southwest Climate Adaptation Science Center, University of Arizona; Environment and Natural Resources 2; 1064 Lowell Street; P.O. Box 210137; Tucson, Arizona 85721 USA; altheawalker@email.arizona.edu

${ }^{1}$ Alaska Humanities Forum; 421 West 1st Ave., Suite 200; Anchorage, Alaska 99501 USA; dwhiting@akhf.org

${ }^{m} \mathrm{Mel}$ and Enid Zuckerman College of Public Health, University of Arizona; 1295 N. Martin Ave.; Drachman Hall; P.O. Box 245210; Tucson, Arizona 85274 USA; jwilson4@email.arizona.edu

${ }^{\mathrm{n}}$ Sixth World Solutions; P.O. Box 199; Lupton, Arizona 86508 USA; janene.y@sixth-world.com

${ }^{\circ}$ Native Nations Institute at the Udall Center for Public Policy and Mel and Enid Zuckerman College of Public Health, University of Arizona; 803 E. First Street; Tucson, Arizona 85719 USA; scrainie@email.arizona.edu

\section{Funding Disclosure}

The Indigenous Foods Knowledges Network was initiated under a National Science Foundation (NSF) grant awarded under the Office of Polar Programs (award number 1745499). The authors gratefully acknowledge the NSF and the Morris K. Udall and Stewart L. Udall Foundation for their financial support. 
researchers to address complex environmental challenges. This movement, primarily driven by Indigenous community leaders and scholars, emphasizes community-driven research that addresses Indigenous People's interests, foregrounds Indigenous Knowledge systems, and both respects and asserts Indigenous sovereignty (see Gupta, 2015; Huntington \& Watson, 2012; Inuit Circumpolar Council Alaska, 2015; Inuit Tapiriit Kanatami, 2018; Ittaq Heritage and Research Center, n.d. ; Johnson, Rowe, Lien, \& López-Hoffman, in press; Kukutai \& Taylor, 2016; Paganelli Votto \& Manuel, 2010; U.S. Indigenous Data Sovereignty Network, n.d.).

This commentary describes one nascent model, the Indigenous Foods Knowledges Network (IFKN), designed to employ the values and methodologies of Indigenous research to connect Indigenous communities and scholars (both Indigenous and non-Indigenous) across the Arctic and the Southwest. IFKN's goal is to foster a network of Indigenous leaders, citizens, and scholars to collectively promote and carry out food sovereignty and resilience knowledge development that (1) utilizes Indigenous research processes, (2) embraces and respects Indigenous Knowledge systems, and (3) supports Indigenous communities (Indigenous Foods Knowledges Network [IFKN], 2018).

IFKN emerged from a U.S. National Science Foundation Research Coordination Network (RCN) grant designed to bring together diverse experts to discuss new ideas and pathways that can be built upon in future projects. A research coordination team from the University of Colorado and the University of Arizona wrote the project proposal and assembled a steering committee composed of nine Indigenous scholars and community leaders from the Arctic and the Southwest. This commentary is the result of gatherings convened in both regions over the last year and is a collaborative output of the steering committee and the research coordination team with input from the broader Network.

What follows is an exploration of some of the emerging ways in which two elements of Indigenous methodologies - relational accountability and centering of story-are fundamental to both the goals and process of IFKN. As we discuss, this is reflected in the initial gatherings of the network partners and its resulting charter. In doing so, we provide an example of how grounding efforts in Indigenous Knowledge systems, asserting Indigenous data sovereignty, and utilizing Indigenous methodologies might support Indigenous food sovereignty broadly and create scholarship that is just, equitable, and accountable to those communities.

\section{A Network Based on Relational Accountability}

The concept of "relational accountability" reflects the centrality of relationship to Indigenous methodologies and knowledge systems (Wilson, 2008, p. 97). Relationships-between individual people, among human collectives, between people and Creation (e.g., earth, waters, animals, plants), and with the spiritual realm-provide the foundations upon which Indigenous Knowledges and worldviews are based (Absolon, 2011; Kovach, 2009; Lambert, 2014; Smith, 2012; Thomas, 2005). These knowledges, including about food, are often shared and expressed in the form of stories to transmit knowledge and worldviews across generations (Basso, 1996; Chilisa, 2011; Kovach, 2009; Lambert, 2014; Thomas, 2005). Indigenous storytelling is a powerful method of transmitting knowledge about how to relate to people and Creation and is also important to transmission of Indigenous languages and subtle modes of expression.

IFKN steering committee member Shawna Larson (Ahtna and Supiaq) offers this story as an example of relational accountability, which she has shared at two IFKN gatherings:

Several years ago, I was at a Tribal Council meeting and one of the elders brought up the fact that in a lot of United States government documents they were using the term "subsistence." He opened the dictionary and read us the definition for subsistence: "the source from which food and other items necessary to subsist are obtained." This definition didn't capture the relationship or the meaning of our way of life. As traditional people, we know that the land and the people are inextricably linked and that we have a very strong relationship with the land and animals. So, be asked me if I would be willing to help find a more traditional word to use. 
I thought that it would be pretty easy to find a substitute word, and I figured that other Tribes would have something already written up on it. If not, I figured that I could always just ask our elders what the word in our own traditional language was. So, I agreed to take on the task and spent some time on the internet, trying to find other Tribes that had done this work. I spent a few weeks researching it, but I wasn't able to find anything that captured the meaning that I was looking for.

Next, I decided to check in with our elders. After several conversation with elders, in which I received answers like "Subsistence is when the berries are ripe, when the fish have arrived, when it's time to bunt moose," I realized that these phrases were not really what I was looking for to express our understanding of "subsistence."

A few months later, I was at a Federal subsistence board meeting with a Yup'ik elder with whom I had worked with in the past. I thought: maybe in the Yup'ik. language they will have a different way to say this. I asked him, and it was so fascinating because his response was exactly the same as what my elders had said. 'When it's time to bunt the seal, when it's time to pick the berries." I said, no that's not really what I meant. He chuckled at me-I'm sure be could see my frustration. I beld up both my hands and pointed to my left hand and said, "if this is the land and the animals. ..." And I beld out my right hand and pointed and said "and this is the people..." And I clasped my hands together and said: "How do we say this?"

And he said "Oh! There is no one word to describe what you're talking about because what you're talking about is a relationship, and in order to understand relationships, we told stories. We told stories because stories make you feel. And feeling is the only way to really describe the responsibility and the relationship that you're talking about with the land, with the animals, and our way of life." I was so struck by his words and all at once, it all made so much sense to me. Our traditional stories are how we tanght our children to behave and have morals, values and respect.

I felt sad that there was no words in English to describe something so important to us. But in the end, I know this relationship and responsibility is something our traditional people have always known and we carry it in our hearts with us wherever we go.

Placing relational accountability and storytelling at the center of IFKN has profound implications for how the Network formed and continues to evolve. One of the most significant ways the Network format facilitates this process is through an emphasis on place-based gatherings. Network gatherings, held once or twice a year, are hosted by Indigenous organizations in Indigenous communities, alternating between the Arctic and the Southwest. Hosts identify relevant projects that are supporting food sovereignty within the community and arrange visits as part of the gathering.

IFKN steering committee member Althea Walker (Akimel O'otham) and the Gila River Indian Community Department of Environmental Quality hosted the first IFKN gathering on March 1 and 2, 2018. Walker and the research coordination team consciously designed the gathering to break down inequities in research relationships that often privilege mainstream scholar voices and ways of knowing. For example, because open-ended conversations foster genuine connections between people, the meeting had a flexible agenda in which participants had ample time to share stories and food, identify goals, and define priorities for the Network. The initial gathering also established relationships that facilitate the remote work necessary to continue building the Network between inperson meetings. Reflecting on the workshop, Walker notes:

To bave the first IFKN meeting on the traditional homelands of the Akimel O'otham and Pii Paash was an honor and a privilege. We were given the opportunity to share our story and provide the Network a firsthand experience of our fight to protect our traditional food and knowledge systems. We've always been farmers, hunters, and gatherers, but when our lifeline, the Gila River, was diverted from our homelands, we were stripped of our traditional diets, making way for famine and disease. It took many years and multiple generations of families to fight and bring back the water to the homelands of the Akimel O'otham and Pii Paash. With the return of the water, our first foods are returning and we are able to share our stories with our 
younger generations through tangible experiences. Hosting the first IFKN meeting, we were able to share our story of how we're rebuilding our ancient irrigation systems, bringing back our traditional foods, and rebuilding our relationship with the land and animals.

Subsequent Network gatherings affirmed the importance of building relationships among the people who constitute IFKN and with the Indigenous homelands that give them strength. Meeting hosts identify places and activities that allow participants to connect with the physical aspects of food, like growing and harvesting, and with ecological and spiritual dimensions of place. At a gathering in March 2019 on the Tohono O'odham Nation, steering committee member and host Amy Juan arranged for the group to visit Waw Gi'wulk, a mountain that is a sacred place for the Tohono O'odham people. The visit created a powerful sense of connection to the land and Spirit among participants, and a closer connection among Network members who hiked, ate together, and exchanged stories about edible plants and food traditions.

\section{Indigenous Foods Knowledges Network: Processes and Guiding Principles}

Following the first IFKN gathering, members of the steering committee and research coordination team drafted a charter with input from the broader Network (IFKN, 2018). The charter articulates the collective vision of IFKN, establishes foundational principles for the Network's work, and lays out initial goals.

\section{Indigenous Foods Knowledges Network Guiding} Principles

- At its core, IFKN serves to support and promote Indigenous sovereignty.

- Research by and with Indigenous Peoples should prioritize community-centered, action-oriented frameworks and foster hands-on exchange of knowledge.

- Indigenous languages are a critical component of food and knowledge sovereignty.

- Demonstrating respect for Indigenous Knowledge systems is a central tenet of IFKN.
- Indigenous communities have authority over research projects that affect them.

- Community concerns over Indigenous foods, seeds, air, lands, and waters, plants, and animals must be identified, recognized and respected when developing partnerships.

- Data are powerful tools for Indigenous communities when they reflect core values.

- Partnerships demand ethical relationships (IFKN, 2018, pp. 2-4).

These principles reflect the centrality of relational accountability and story in the IFKN operating framework, emphasizing respect for Indigenous Knowledge systems and highlighting ways to support Indigenous Knowledge sovereignty, including Indigenous food knowledges.

\section{From Principles to Action: Network Goals} The IFKN Charter also delineates goals to orient collaboration and support our work together. Like the principles, these goals were derived from conversations at the inaugural Network meeting. The goals are (1) take action!, (2) connect across generations, (3) engage Indigenous scholars, (4) support Indigenous Knowledge systems as defined and represented by Indigenous Peoples, (5) support Indigenous research and data governance, (6) advocate for ethical research and data partnerships, (7) work across multiple scales, and (8) establish a Network of Networks (IFKN, 2018, pp. 4-5).

The provocation, To whom are we accountable in our research?, summarizes the relational accountability interwoven through the principles and goals. The goals also reflect the Network's interest in facilitating collaboration to reorient both research and practice on Indigenous foods in support of Indigenous sovereignty.

\section{Anticipating and Responding to Challenges}

While IFKN is still in its formative stages, we have already engaged with challenges related to enacting the principles of relational accountability in the way that we interact with Indigenous communities.

Recognizing that Indigenous communities, 
organizations, and representatives have high demands on their time, it is important to approach them with attention to what IFKN offers in return. With each step we are conscious to consider the following questions: (1) How might involvement in this Network benefit the community? (2) How can Network gatherings be organized to ensure meaningful connections between visitors and hosts? (3) How can we ensure that all participants (hosts and visitors) come away with a better sense of their goals and challenges in relation to food sovereignty?

Breaking down power imbalances in Network processes and being inclusive are related challenges. Academic researchers submitted the proposal, administer the grant, and coordinate the Network to keep the administrative burden off Indigenous community partners. This raises the question of whether this structure reflects the inclusivity that the Network aims to foster. Ensuring that active Network members are compensated for their time and effort - to the extent possible within a grant-is one way we are trying to bridge this gap.

IFKN is, and will continue to be, challenged to remain true to relational accountability. IFKN as a collective, and its individual members must continue to explore ways to build be in service to and in ongoing relationship with the communities that are working to strengthen foodways, food sovereignty, and data governance. Given the recent emergence of IFKN, the ways in which such relational accountability will develop remains uncertain. The answer will emerge from relationshipbuilding and a commitment to accountability over the coming years. We will navigate these and challenges we cannot anticipate by learning from existing Indigenous networks and drawing on the experience and wisdom of IFKN members.

\section{Where Do We Go From Here?}

IFKN is designed to employ the values and processes of Indigenous research to connect Indigenous communities and scholars across the Arctic and the Southwest U.S. IFKN is an example of what Peter Reason refers to as "building democratic, participative, pluralistic communities of inquiry" (2003, p. 109) that embrace "ways of knowing that go beyond the orthodox empirical and rational Western epistemology, and which start from a relationship between self and other, through participation" (p. 111). In this process, knowledge shared through stories is emergent from and contingent on the quality of relationships, which are at the heart of our collective work. The impacts of this work are reflected in the stories that participants share. We close with these words from Althea Walker:

As an Indigenous woman with ancestry from
southern and northern tribes, networks like the
IFKN are vital to keeping our old ways alive and
ensuring that our knowledge lives on through our
children. Being a part of the IFKN has allowed me
to continue to learn more about who I am, where I
come from, and where I'm going.

\section{Acknowledgments}

This article has many contributors. Primary thanks go to our knowledge keepers, including the land and our nonhuman kin. Also, thank you to the authors and to the members and partners of the Indigenous Foods Knowledges Network. We thank the youth who will continue keeping and sharing our knowledges with generations to come, especially around traditional foods. We acknowledge the researchers, particularly Indigenous scholars, who are community-driven and include Indigenous communities as true partners in research.

\section{References}

Absolon, K. E. (2011). Kaandossiwin: How we come to know. Halifax, Nova Scotia, Canada: Fernwood Publishing.

Basso, K. H. (1996). Wisdom sits in places: Landscape and language among the Western Apache. Albuquerque: University of New Mexico Press.

Chilisa, B. (2011). Indigenous research methodologies. Los Angeles: Sage Publication.

Gupta, C. (2015). Return to freedom: Anti-GMO Aloha 'Āina activism on Molokai as an expression of place-based food sovereignty. Globalizations, 12(4), 529-544. https://doi.org/10.1080/14747731.2014.957586 
Huntington, O. H., \& Watson, A. (2012). Interdisciplinarity, Native resilience, and how the riddles can teach wildlife law in an era of rapid climate change. Wicazo Sa Review, 27(2), 49-73. https://doi.org/10.5749/wicazosareview.27.2.0049

Indigenous Foods Knowledges Network (IFKN). (2018). Indigenous Foods Knowledges Network Charter. Retrieved from http://ifkn.org/sites/default/files/IFKN final charter network.pdf

Inuit Circumpolar Council Alaska. (2015). Alaskan Inuit food security conceptual framework: how to assess the arctic from an Inuit perspective. Retrieved from https://iccalaska.org/wp-icc/wp-content/uploads/2016/03/Food-Security-Summaryand-Recommendations-Report.pdf

Inuit Tapiriit Kanatami. (2018). National Inuit strategy on research. Retrieved from https://www.itk.ca/wp-content/uploads/2018/03/National-Inuit-Strategy-on-Research.pdf

Ittaq Heritage and Research Center. (n.d.) Clyde River Knowledge Atlas. Retrieved from https://clyderiveratlas.ca/index.html

Johnson, M. K., Rowe, M. J., Lien, A., \& López-Hoffman, L. (in press). Examining compatibility and conflicts in the integration of indigenous agricultural knowledge into National Resource Conservation Service cost-share initiatives. Manuscript in process.

Kovach, M. (2009). Indigenous methodologies: Characteristics, conversations, and contexts. Toronto: University of Toronto Press.

Kukutai, T., \& Taylor, J. (2016). Data sovereignty for Indigenous peoples: Current practices and future needs. In T. Kukutai \& J. Taylor (Eds.), Indigenous data sovereignty: Toward an agenda (pp. 1-22). Canberra: Australian National University Press. https://doi.org/10.22459/CAEPR38.11.2016

Lambert, L. A. (2014). Research for Indigenous survival: indigenous research methodologies in the behavioral sciences. Pablo, Montana: Salish Kootenai College Press.

Paganelli Votto, M., \& Manuel, F. S. (2010). From I'itoi's garden: Tohono O'odham food traditions. Sells, Arizona: Tohono O’odham Community Action TOCA \& Blurb.

Reason, P. (2003). Pragmatist philosophy and action research: Readings and conversation with Richard Rorty. Action Research, 1(1), 103-123. https://doi.org/10.1177/14767503030011007

Smith, L. T. (2012). Decolonizing methodologies: Research and Indigenous peoples. London: Zed Books.

Thomas, R. A. (2005). Honoring the oral traditions of my ancestors through storytelling. In L. Brown \& S. Strega (Eds.), Research as resistance: critical, indigenous and anti-oppressive approaches (pp. 177-198). Toronto: Canadian Scholars' Press.

U.S. Indigenous Data Sovereignty Network. (n.d.). About us. Retrieved from https://usindigenousdata.org/about-us Wilson, S. (2008). Research is ceremony: Indigenous research methods. Halifax, Nova Scotia: Fernwood Publishing. 